\title{
Teachers and Parents' Perception toward English as a Local Content Subject at Elementary School in Banjarmasin
}

\author{
Rina Listina, Irene Yudhistira \\ English Department \\ Faculty of Teacher Training and Education \\ Universitas Lambung Mangkurat \\ Banjarmasin, Indonesia \\ rina_listia@ulm.ac.id, ireinayudhistira@gmail.com
}

\begin{abstract}
Despite the policy of English as a local content subject in Indonesia's elementary school, the process of teaching and learning English is still relevant. However, some aspects need to be considered in implementing the policy, for instance, teachers and parents' perception. This research is intended to find out about teacher and parents' perception toward the implementation of English as a local content subject in SDN Pemurus Dalam 3 Banjarmasin. This research used descriptive quantitative approach. The subjects consisted of 10 teachers and 108 parents. The data were collected by using 4-point Likert scale questionnaires that was distributed to teachers and student's parents. In analyzing the data, the researcher used descriptive statistic by calculating mean, standard deviation, and categorized the total score. The result of the study indicated that all teachers' perception toward English as a local content subject in SDN Pemurus Dalam 3 Banjarmasin belonged to high agreement category. For parents, there were 80 parents $(\mathbf{7 4 . 1 \%})$ which belonged to high agreement category and 28 parents $(25.9 \%)$ which belonged to moderate agreement category. As suggestions, teachers and parents' positive perception should be complemented with their understanding of young learners' characteristics and English for young learner's principle. Moreover, the government should also consider teachers and parents' perception in making future policy related to English for young learner.
\end{abstract}

Keywords—perception, english, local content

\section{INTRODUCTION}

In Indonesia, English was initially introduced to elementary school students in the 1994 curriculum. According to reference [1], the policy about English language learning in elementary school was positively accepted.

In several years, the curriculum in Indonesian has changed several times with the purpose of improving the education. Recently, reference [2] described that in 2013 Curriculum, English cannot be learnt as curricular subject as in the previous curriculum. This policy caused different implementation of English subject from one elementary school to another.

The policy about "removing" English subject as compulsory subject is based on the decision to simplify the curriculum in elementary school. In contrast, some people including parents, teacher, and society agreed that English learning in elementary school is essential. This was supported by reference [3] that one of the reasons that underlying the decision to introduce English to young learners is political reasons. Indonesian's people are being prepared to be able to adapt with globalization era where distance is no longer becomes barrier to communicate.

Despite the policy of English as a local content subject in elementary school, it seems that process of teaching and learning English is still important. Nevertheless, some aspects need to be considered with the purpose of implementing English as local content subject in specific school, for example, perception. In his study, reference [4] suggested that students' and other stakeholders' perceptions towards the status of English as local content subject is also important. It can be concluded that perception need to be counted in purpose of implementing English as a local content subject in elementary school and one of them in SDN Pemurus Dalam 3 Banjarmasin.

In conclusion, based on the explanation and the background of study above, the problem of the research can be formulated as follows; "What are teachers and parents' perception toward the implementation of English as local content subject in SDN Pemurus Dalam 3 Banjarmasin?"

\section{METHOD}

The researcher used descriptive quantitative approach. This approach was chosen due to the aim of this research to describe the teachers and parents' perception toward the implementation of English as a local content subject in SDN Pemurus Dalam 3 Banjarmasin. Descriptive quantitative is an approach where the researcher describe characteristic from a population or phenomenon with the number and statistical data to answer the research problem.

The data of this research taken from two sources: teachers and parents, which consisted of 10 teachers and 108 parents. 4Likert scale questionnaires were used to examine teachers and parents' perceptions toward the implementation of English as a local content subject in SDN Pemurus Dalam 3 Banjarmasin. The researcher adapted the questionnaires used by reference [5] 
for teacher's questionnaire and from reference [6] for parents' questionnaires. The reliability score of both instruments were .858 and .944 . The steps in analyzing the data is mentioned as follows:

- The researcher scored the questionnaire according to the score of options' table from each item then the scores being summed up. As a result, the researcher had the total score of each subjects.

- The researcher define the qualification score level of perception by calculating the hypothetic mean and hypothetic standard deviation.

- The researcher categorized the participants' score based on the level in qualification score of perception which divided into three categories: high, moderate, and low.

- The researcher concluded the findings according the data being obtained.

\section{RESULT AND DISCUSSION}

\section{A. Teachers'Perception}

To find out about teacher's perception toward English as a local content subject, the data which consists of questionnaire was being analyzed. The process of data analysis was done by summed up the score of each subject and categorized the scores into three categories: high, moderate, and low, while the teacher's perception, in general, can be seen in Table 1 .
TABLE I. TEACHERS' PERCEPTION TOWARD ENGLISH AS A LOCAL CONTENT SUBJECT IN SDN PEMURUS DALAM 3 BANJARMASIN

\begin{tabular}{|c|l|l|}
\hline Category & Frequency & $\begin{array}{c}\text { Percentage } \\
(\%)\end{array}$ \\
\hline High & 10 & 100 \\
\hline Moderate & 0 & 0 \\
\hline Low & 0 & 0 \\
\hline Total & 10 & $\mathbf{1 0 0}$ \\
\hline
\end{tabular}

Based on the result in Table 1 above, all teachers' responses toward English as a local content subject belonged to high category of perception in which there was no response belonged to moderate category and low category of perception. It can be concluded that teachers' perception toward English as a local content subject in SDN Pemurus Dalam 3 Banjarmasin was categorized as high category of perception or they had positive perception.

The teacher' perception toward English as a local content subject in SDN Pemurus Dalam 3 Banjarmasin, frequencies, mean and percentages of their responses were also analyzed on the topic of statements related to four aspects: knowledge, view, need, and attention.

In teacher's questionnaire, statement number one to number seven consist of the statements that related to knowledge aspect. In detail, statement number 1, 2, and 7 were about teachers' knowledge about English in general, then statement number 3, 4, 5, and six about the purpose of English as a local content subject in elementary school.

TABLE II. TEACHERS' RESPONSE IN KNOWLEDGE ASPECT

\begin{tabular}{|c|c|c|c|c|c|c|c|c|c|c|}
\hline \multirow{3}{*}{ Item } & \multicolumn{8}{|c|}{ Response } & \multirow{3}{*}{ Total } & \multirow{3}{*}{ Mean Score } \\
\hline & \multicolumn{2}{|c|}{ Strongly Agree } & \multicolumn{2}{|c|}{ Agree } & \multicolumn{2}{|c|}{ Disagree } & \multicolumn{2}{|c|}{$\begin{array}{l}\text { Strongly } \\
\text { Disagree }\end{array}$} & & \\
\hline & $N$ & $\%$ & $N$ & $\%$ & $N$ & $\%$ & $N$ & $\%$ & & \\
\hline 1 & 6 & 60 & 4 & 40 & 0 & 0 & 0 & 0 & 36 & 3.6 \\
\hline 2 & 6 & 60 & 4 & 40 & 0 & 0 & 0 & 0 & 36 & 3.6 \\
\hline 3 & 5 & 50 & 5 & 50 & 0 & 0 & 0 & 0 & 35 & 3.5 \\
\hline 4 & 4 & 40 & 6 & 60 & 0 & 0 & 0 & 0 & 34 & 3.4 \\
\hline 5 & 0 & 0 & 10 & 100 & 0 & 0 & 0 & 0 & 30 & 3.0 \\
\hline 6 & 2 & 20 & 8 & 80 & 0 & 0 & 0 & 0 & 32 & 3.2 \\
\hline 7 & 8 & 80 & 2 & 20 & 0 & 0 & 0 & 0 & 37 & 3.7 \\
\hline
\end{tabular}

Item number eight to item number thirteen consist of the statements related to view aspect. In detail, item number 8 and nine consist of the statements about teachers' view toward their role and parents' role in the process of English learning.
Also, item number $10,11,12$, and 13 about teachers' view toward the policy that related to English as local content subject.

TABLE III. TEACHERS' RESPONSE IN VIEW ASPECT

\begin{tabular}{|c|c|c|c|c|c|c|c|c|c|c|}
\hline \multirow{3}{*}{ Item } & \multicolumn{8}{|c|}{ Response } & \multirow{3}{*}{ Total } & \multirow{3}{*}{$\begin{array}{l}\text { Mean } \\
\text { Score }\end{array}$} \\
\hline & \multicolumn{2}{|c|}{ Strongly Agree } & \multicolumn{2}{|c|}{ Agree } & \multicolumn{2}{|c|}{ Disagree } & \multicolumn{2}{|c|}{$\begin{array}{l}\text { Strongly } \\
\text { Disagree }\end{array}$} & & \\
\hline & $N$ & $\%$ & $N$ & $\%$ & $N$ & $\%$ & $N$ & $\%$ & & \\
\hline 8 & 5 & 50 & 5 & 50 & 0 & 0 & 0 & 0 & 35 & 3.5 \\
\hline 9 & 2 & 20 & 8 & 80 & 0 & 0 & 0 & 0 & 32 & 3.2 \\
\hline 10 & 0 & 0 & 10 & 100 & 0 & 0 & 0 & 0 & 30 & 3.0 \\
\hline 11 & 0 & 0 & 10 & 100 & 0 & 0 & 0 & 0 & 30 & 3.0 \\
\hline 12 & 2 & 20 & 8 & 80 & 0 & 0 & 0 & 0 & 32 & 3.2 \\
\hline 13 & 2 & 20 & 8 & 80 & 0 & 0 & 0 & 0 & 32 & 3.2 \\
\hline
\end{tabular}


Item number 14 to item number 19 consist of the statements related to teachers' need aspect. In detail, item number 14 and 15 consist of the statements about teachers' facilities, item number 16 and 17 about school's facilities, and item number 18 and 19 about parents' cooperation in English teaching-learning process.

TABLE IV. TEACHERS' RESPONSE IN NEED ASPECT

\begin{tabular}{|c|c|c|c|c|c|c|c|c|c|c|}
\hline \multirow{3}{*}{ Item } & \multicolumn{8}{|c|}{ Response } & \multirow{3}{*}{ Total } & \multirow{3}{*}{$\begin{array}{l}\text { Mean } \\
\text { Score }\end{array}$} \\
\hline & \multicolumn{2}{|c|}{ Strongly Agree } & \multicolumn{2}{|c|}{ Agree } & \multicolumn{2}{|c|}{ Disagree } & \multicolumn{2}{|c|}{$\begin{array}{l}\text { Strongly } \\
\text { Disagree }\end{array}$} & & \\
\hline & $N$ & $\%$ & $N$ & $\%$ & $N$ & $\%$ & $N$ & $\%$ & & \\
\hline 14 & 4 & 40 & 5 & 50 & 1 & 10 & 0 & 0 & 33 & 3.3 \\
\hline 15 & 2 & 20 & 8 & 80 & 0 & 0 & 0 & 0 & 32 & 3.2 \\
\hline 16 & 1 & 10 & 7 & 70 & 2 & 20 & 0 & 0 & 29 & 2.9 \\
\hline 17 & 1 & 10 & 8 & 80 & 1 & 10 & 0 & 0 & 30 & 3.0 \\
\hline 18 & 4 & 40 & 6 & 60 & 0 & 0 & 0 & 0 & 34 & 3.4 \\
\hline 19 & 6 & 60 & 4 & 40 & 0 & 0 & 0 & 0 & 36 & 3.6 \\
\hline
\end{tabular}

Item number 20 to item number 25 consist of the statements related to teachers' attention aspect. In detail, item number 20 and 21 consist of the statements about teachers' attention toward the students and item number 22, 23, 24, and 25 about teachers' attitude toward the implementation of English as a local content subject.

TABLE V. TEACHERS’ RESPONSE IN ATTENTION ASPECT

\begin{tabular}{|c|c|c|c|c|c|c|c|c|c|c|}
\hline \multirow{3}{*}{ Item } & \multicolumn{8}{|c|}{ Response } & \multirow{3}{*}{ Total } & \multirow{3}{*}{$\begin{array}{l}\text { Mean } \\
\text { Score }\end{array}$} \\
\hline & \multicolumn{2}{|c|}{ Strongly Agree } & \multicolumn{2}{|c|}{ Agree } & \multicolumn{2}{|c|}{ Disagree } & \multicolumn{2}{|c|}{$\begin{array}{l}\text { Strongly } \\
\text { Disagree } \\
\end{array}$} & & \\
\hline & $N$ & $\%$ & $N$ & $\%$ & $N$ & $\%$ & $N$ & $\%$ & & \\
\hline 20 & 5 & 50 & 5 & 50 & 0 & 0 & 0 & 0 & 35 & 3.5 \\
\hline 21 & 3 & 30 & 7 & 70 & 0 & 0 & 0 & 0 & 33 & 3.3 \\
\hline 22 & 4 & 40 & 6 & 60 & 0 & 0 & 0 & 0 & 34 & 3.4 \\
\hline 23 & 5 & 50 & 5 & 50 & 0 & 0 & 0 & 0 & 35 & 3.5 \\
\hline 24 & 2 & 20 & 8 & 80 & 0 & 0 & 0 & 0 & 32 & 3.2 \\
\hline 25 & 3 & 30 & 7 & 70 & 0 & 0 & 0 & 0 & 33 & 3.3 \\
\hline
\end{tabular}

\section{B. Parents'Perception}

To find out about parents' perception toward English as a local content subject, the data which consists of parents' questionnaire, was being analyzed. The process of data analysis was done by summing up the score of each subject and categorize the scores into three categories: high, moderate, and low. The parents' perception category, in general, can be seen in Table 6 as follows:

TABLE VI. PARENTS' PERCEPTION TOWARD ENGLISH AS A LOCAL CONTENT SUBJECT IN SDN PEMURUS DALAM 3

\begin{tabular}{|c|l|l|}
\hline Category & \multicolumn{1}{|c|}{ Frequency } & \multicolumn{1}{|c|}{ Percentage (\%) } \\
\hline High & 80 & 74.1 \\
\hline Moderate & 28 & 25.9 \\
\hline Low & 0 & 0 \\
\hline Total & $\mathbf{1 0 8}$ & $\mathbf{1 0 0}$ \\
\hline
\end{tabular}

Based on the result in Table 6 above, most of the parents' perception toward English as a local content subject belonged to high category of perception in which there were 80 parents (74.1\%), then was followed by 28 parents $(25.9 \%)$ which belonged to moderate category, and there was no parent who belongs to low level of perception. It can be concluded that parents' perception toward English as a local content subject in SDN Pemurus Dalam 3 Banjarmasin was categorized as high level of perception.
The parents' perception toward English as a local content subject in SDN Pemurus Dalam 3 Banjarmasin, frequencies, mean and percentages of their responses were also analyzed on the topic of statements related to the four aspects: knowledge, attention, attitude, and view.

In parents' questionnaire, statement number one to number seven consist of the statements that related to knowledge aspect. In detail, statement number 1,2, 3, and 4 were about parents' knowledge related to English in general, then statement number 5, 6, and seven about knowledge related to 
the purpose of English as a local content subject in elementary school.

TABLE VII.

PARENTS' RESPONSE IN KNOWLEDGE ASPECT

\begin{tabular}{|c|c|c|c|c|c|c|c|c|c|c|}
\hline \multirow{3}{*}{ Item } & \multicolumn{8}{|c|}{ Response } & \multirow{3}{*}{ Total } & \multirow{3}{*}{$\begin{array}{l}\text { Mean } \\
\text { score }\end{array}$} \\
\hline & \multicolumn{2}{|c|}{ Strongly Agree } & \multicolumn{2}{|c|}{ Agree } & \multicolumn{2}{|c|}{ Disagree } & \multicolumn{2}{|c|}{$\begin{array}{l}\text { Strongly } \\
\text { Disagree }\end{array}$} & & \\
\hline & $N$ & $\%$ & $N$ & $\%$ & $N$ & $\%$ & $N$ & $\%$ & & \\
\hline 1 & 49 & 45.4 & 54 & 50.0 & 4 & 3.7 & 1 & 0.9 & 367 & 3.40 \\
\hline 2 & 47 & 43.5 & 54 & 50.0 & 7 & 6.5 & 0 & 0.0 & 364 & 3.37 \\
\hline 3 & 39 & 36.1 & 65 & 60.2 & 4 & 3.7 & 0 & 0.0 & 359 & 3.32 \\
\hline 4 & 40 & 37.0 & 68 & 63.0 & 0 & 0.0 & 0 & 0.0 & 364 & 3.37 \\
\hline 5 & 53 & 49.1 & 52 & 48.1 & 2 & 1.9 & 1 & 0.9 & 373 & 3.45 \\
\hline 6 & 28 & 25.9 & 75 & 69.4 & 4 & 3.7 & 1 & 0.9 & 346 & 3.20 \\
\hline 7 & 25 & 23.1 & 74 & 68.5 & 8 & 7.4 & 1 & 0.9 & 339 & 3.14 \\
\hline
\end{tabular}

Item number eight to number thirteen consist of the statements that related to attention aspect. In detail, statement number 8,9 , and 10 were connected to parents' attention toward their children, then statement number 11,12 , and 13 about parents' role in English learning process.

\section{TABLE VIII. PARENTS' RESPONSE IN ATTENTION ASPECT}

\begin{tabular}{|c|c|c|c|c|c|c|c|c|c|c|}
\hline \multirow{3}{*}{ Item } & \multicolumn{8}{|c|}{ Response } & \multirow{3}{*}{ Total } & \multirow{3}{*}{$\begin{array}{l}\text { Mean } \\
\text { score }\end{array}$} \\
\hline & \multicolumn{2}{|c|}{ Strongly Agree } & \multicolumn{2}{|c|}{ Agree } & \multicolumn{2}{|c|}{ Disagree } & \multicolumn{2}{|c|}{$\begin{array}{l}\text { Strongly } \\
\text { Disagree }\end{array}$} & & \\
\hline & $N$ & $\%$ & $N$ & $\%$ & $N$ & $\%$ & $N$ & $\%$ & & \\
\hline 8 & 28 & 25.9 & 68 & 63.0 & 14 & 13 & 0 & 0.0 & 344 & 3.19 \\
\hline 9 & 31 & 28.7 & 69 & 63.9 & 8 & 7.4 & 0 & 0.0 & 347 & 3.21 \\
\hline 10 & 16 & 14.8 & 80 & 74.1 & 11 & 10.2 & 1 & 0.9 & 327 & 3.03 \\
\hline 11 & 31 & 28.7 & 73 & 67.6 & 2 & 1.9 & 2 & 1.9 & 349 & 3.23 \\
\hline 12 & 46 & 42.6 & 58 & 53.7 & 4 & 3.7 & 0 & 0.0 & 366 & 3.39 \\
\hline 13 & 38 & 35.2 & 67 & 62.0 & 3 & 2.8 & 0 & 0.0 & 359 & 3.32 \\
\hline
\end{tabular}

Item number fourteen to number nineteen consist of the statements related to attitude aspect. In detail, statement number $14,15,16$, and 17 were connected to parents' support, then statement number 18 and 19 about the learning facilities that were provided by parents.

TABLE IX.

PARENTS’ RESPONSE IN ATTITUDE ASPECT

\begin{tabular}{|c|c|c|c|c|c|c|c|c|c|c|}
\hline \multirow{3}{*}{ Item } & \multicolumn{8}{|c|}{ Response } & \multirow{3}{*}{ Total } & \multirow{3}{*}{ Mean score } \\
\hline & \multicolumn{2}{|c|}{ Strongly Agree } & \multicolumn{2}{|c|}{ Agree } & \multicolumn{2}{|c|}{ Disagree } & \multicolumn{2}{|c|}{$\begin{array}{l}\text { Strongly } \\
\text { Disagree } \\
\end{array}$} & & \\
\hline & $N$ & $\%$ & $N$ & $\%$ & $N$ & $\%$ & $N$ & $\%$ & & \\
\hline 14 & 25 & 23.1 & 72 & 66.7 & 10 & 9.3 & 1 & 0.9 & 337 & 3.12 \\
\hline 15 & 40 & 37.0 & 62 & 57.4 & 6 & 5.6 & 0 & 0.0 & 358 & 3.31 \\
\hline 16 & 51 & 47.2 & 57 & 52.8 & 0 & 0.0 & 0 & 0.0 & 375 & 3.47 \\
\hline 17 & 21 & 19.4 & 79 & 73.1 & 9 & 8.3 & 1 & 0.9 & 340 & 3.15 \\
\hline 18 & 23 & 21.3 & 76 & 70.4 & 9 & 8.3 & 0 & 0.0 & 338 & 3.13 \\
\hline 19 & 14 & 13.0 & 71 & 65.7 & 23 & 21.3 & 0 & 0.0 & 338 & 3.13 \\
\hline
\end{tabular}

Item number twenty to number twenty-five consists of the statements related to view aspect. In detail, statement number 20, 21, and 22 were connected to parents' view toward school's policy, then statement number 23, 24, and 25 about school's facilities related to the process of teaching and learning English as a local content subject. 
TABLE X.

PARENTS’ RESPONSE IN VIEW ASPECT

\begin{tabular}{|c|c|c|c|c|c|c|c|c|c|c|}
\hline \multirow{3}{*}{ Item } & \multicolumn{8}{|c|}{ Response } & \multirow{3}{*}{ Total } & \multirow{3}{*}{ Mean } \\
\hline & \multicolumn{2}{|c|}{ Strongly Agree } & \multicolumn{2}{|c|}{ Agree } & \multicolumn{2}{|c|}{ Disagree } & \multicolumn{2}{|c|}{$\begin{array}{l}\text { Strongly } \\
\text { Disagree } \\
\end{array}$} & & \\
\hline & $N$ & $\%$ & $N$ & $\%$ & $N$ & $\%$ & $N$ & $\%$ & & \\
\hline 20 & 27 & 25 & 73 & 67.6 & 8 & 7.4 & 0 & 0.0 & 343 & 3.18 \\
\hline 21 & 23 & 21.3 & 77 & 71.3 & 8 & 7.4 & 0 & 0.0 & 339 & 3.14 \\
\hline 22 & 25 & 23.1 & 75 & 69.4 & 5 & 4.6 & 3 & 2.8 & 338 & 3.13 \\
\hline 23 & 22 & 20.4 & 82 & 75.9 & 4 & 3.7 & 0 & 0.0 & 342 & 3.17 \\
\hline 24 & 8 & 7.4 & 87 & 80.5 & 13 & 12 & 0 & 0.0 & 319 & 2.95 \\
\hline 25 & 10 & 9.3 & 88 & 81.8 & 8 & 7.4 & 2 & 1.9 & 322 & 2.98 \\
\hline
\end{tabular}

\section{Teachers' Perception}

From the research finding, it indicated that all teachers' response were belonged to high agreement category of perception. The knowledge aspect had the highest mean scores. All teachers in SDN Pemurus Dalam 3 Banjarmasin agreed that the use of media such as storybooks, pictorial dictionary, and English lesson book were essential to support young learner in learning English. It was related to what reference [1] said that English for young learner learning process will be more effective if it is followed by the use of media such picture, audio, or flash cards that attracts their attention.

Despite teachers' positive perception toward the implementation of English as a local content subject in SDN Pemurus Dalam 3 Banjarmasin, the statement in teachers' need aspect had the lowest mean score. Some teachers agreed that the facility that provided by school was not sufficient enough, especially the facility that needed by English teacher; for example, no language laboratory support teacher to have variety activity for students. It was related to what reference [7] mentioned that nowadays, teacher especially English teachers are demanded to be creative in making simple teaching media to gain students' interest.

\section{Parents' Perception}

The research finding indicated that that parents' perceptions toward English as a local content subject in SDN Pemurus Dalam 3 Banjarmasin were divided into high agreement category and moderate agreement category, in which high agreement category consisted of $74.1 \%$ parents while moderate agreement category consisted of $25.9 \%$ parents.

In parents' perception, knowledge aspect had the highest mean scores in parents' perception. Most parents agreed that the implementation of English in elementary school will support their children's knowledge in higher level of education. It is related to what reference [3] said that the introduction of foreign language is considered as a positive act for the further level of language acquisition. In spite of parents' positive response in knowledge aspect, the statement in view aspect had the lowest mean score. By teachers' perception, parents thought that the facility that provided by school was not sufficient enough to support the implementation of English as a local content subject in SDN Pemurus Dalam 3 Banjarmasin. Following reference [8] that the lack of school's facilities and infrastructures, for examples classroom, library, and laboratory, have become serious problem that faced by education world in Indonesia.

\section{CONCLUSION}

The conclusions of the research were mentioned as follow:

- All teachers' perception toward English as a local content subject in SDN Pemurus Dalam 3 Banjarmasin belonged to high agreement category of perception.

- The highest mean score was gained by statement in knowledge aspect, that related to the use of media in English learning process, while the lowest mean score was obtained by statement in need aspect which analyzed whether the facility that provided by school such as dictionary, book, or audio was sufficient enough.

- Most parents' perception toward English as a local content subject in SDN Pemurus Dalam 3 Banjarmasin belonged to high agreement category of perception in which there were 80 parents $(74.1 \%)$, then was followed by 28 parents (25.9\%) who belonged to moderate agreement category, and there was no parent who belongs to low agreement category of perception.

- The highest mean score was gained by the statement related to parents' knowledge about the goal of English as a local content subject in elementary school level. On the other hand, the lowest mean score was gained by statement which analyzed parents' view whether the school facilities such as dictionary, book, or audio have fulfilled their children's need.

\section{REFERENCES}

[1] K. K. E. Suyanto, English for Young Learners. Jakarta: Bumi Aksara, 2009.

[2] N. Arif, "Removing english as compulsory subject from primary schools on the 2013 curriculum based on teachers' opinion," International Journal of Scientific and Research Publications, vol. 5, no. 8, pp. 1-5, 2015.

[3] S. Hawanti, "Teaching english in Indonesian Primary Schools: The Missing Link," Leksika, vol.5, no. 1, pp. 62-69, 2011.

[4] Iskandar, "Putting English as a Local Content Subject in Primary Schools: Teachers' Belief and Its Impact on Their Teaching Delivery," 2015. [Online]. Available: https://www.researchgate.net/publication/319016760 retrieved on. 
[5] K. M. Habeeb, Teachers' Perceptions toward Implementing English as a Foreign Language at Kindergarten: What Can We Learn from the Case of Kuwaiti Kindergarten Teachers?. Dissertations. University of Arkansas, 2013.

[6] R. H. Faqihatuddiniyah, "Persepsi orang tua dan guru mengenai bahasa inggris pada anak usia dini di TK Aba Karangmalang Yogyakarta," Jurnal Tarbiyah, vol. 6, no. 2, pp. 29-39, 2017.
[7] I. M. Sujana, I. Made, L. S. Narasutawati, "Bahasa Inggris untuk Sekolah Dasar: mau ke mana?," Jurnal Pendidikan Penabur, vol. 1, no. $1,2006$.

[8] Daryanto, Inovasi Pembelajaran Efektif. Bandung: Yrama Widya, 2013. 